\title{
Research Article \\ Effects of Zinc Oxide Nanoparticles on the Properties of Pectin/Alginate Edible Films
}

\author{
Thi Minh Phuong Ngo, ${ }^{1}$ Thi Mong Quyen Dang, ${ }^{2}$ Thi Xo Tran, ${ }^{3}$ \\ and Pornchai Rachtanapun (iD) \\ ${ }^{1}$ The University of Danang - University of Technology and Education, Da Nang, Vietnam \\ ${ }^{2}$ College of Food Industry, Da Nang, Vietnam \\ ${ }^{3}$ The University of Danang - University of Science and Technology, Da Nang, Vietnam \\ ${ }^{4}$ Division of Packaging Technology, Faculty of Agro-Industry, Chiang Mai University, Chiang Mai 50100, Thailand \\ ${ }^{5}$ Center of Excellent in Materials Science and Technology, Chiang Mai University, Chiang Mai 50200, Thailand
}

Correspondence should be addressed to Pornchai Rachtanapun; pornchai.r@cmu.ac.th

Received 9 July 2018; Revised 24 August 2018; Accepted 2 September 2018; Published 22 October 2018

Guest Editor: Ing Kong

Copyright ( 2018 Thi Minh Phuong Ngo et al. This is an open access article distributed under the Creative Commons Attribution License, which permits unrestricted use, distribution, and reproduction in any medium, provided the original work is properly cited.

\begin{abstract}
This study aimed at developing the functional packaging properties of pectin/alginate films by adding zinc oxide nanoparticles ( $\mathrm{ZnO}-\mathrm{NPs}$ ). The $\mathrm{ZnO}-\mathrm{NPs}$ were added to the pectin/alginate film at the concentrations of $0.5,2.5,5$, and $25 \mathrm{~g} / 100 \mathrm{~g}$ of blended polymer. The effects of the $\mathrm{ZnO}-\mathrm{NP}$ incorporation on the mechanical properties, hydration properties, oxygen permeability, ultraviolet transmission, transparency, and antimicrobial activity of the films were investigated. The addition of $\mathrm{ZnO}-\mathrm{NPs}$ from 0 to $5 \mathrm{~g} / 100 \mathrm{~g}$ of blended polymer to the pectin/alginate film increased $191.4 \%$ of the tensile strength, $169.8 \%$ of elongation at break, and antimicrobial properties (against Aspergillus niger, Colletotrichum gloeosporioides, Escherichia coli, and Saccharomyces cerevisiae). In contrast, it reduced the solubility from $30.38 \%$ to $22.49 \%$, water vapor permeability from $1.01 \times 10^{-14}$ to $0.414 \times 10^{-14} \mathrm{~kg} \cdot \mathrm{m} / \mathrm{m}^{2} \cdot \mathrm{Pa} \cdot \mathrm{s}$, moisture absorption, ultraviolet light transmission, and oxygen permeability from $270.86 \times 10^{-19}$ to $110.79 \times 10^{-19} \mathrm{~kg} \cdot \mathrm{m} / \mathrm{m}^{2} \cdot \mathrm{Pa} \cdot \mathrm{s}$. The effects are the highest when the concentration of the ZnO-NPs in the film was $5 \mathrm{~g} / 100 \mathrm{~g}$ of blended polymer. Attenuated total reflectance-Fourier transform infrared analysis indicated that some interactions between the $\mathrm{ZnO}-\mathrm{NPs}$ and pectin/alginate matrices were formed. These results suggest that pectin/alginate/ZnO-NPs films can be used as active packaging for food preservation.
\end{abstract}

\section{Introduction}

Food packaging materials with proper mechanical strength; barrier properties against water, water vapor, and other gases; thermal stability, recyclability, and biodegradability; and functional properties, such as antimicrobial activities, are highly desirable for food safety and extending the shelf-life of packaged foods [1]. However, biopolymer-based packaging materials have not been widely used in the packaging industry, mainly because of their poor mechanical, barrier, and processing properties. They also have a higher production cost compared to commodity plastic films [2]. Edible films are increasingly used in food preservation, and they are largely produced from nontoxic polysaccharide sources. Among various polysaccharides, pectin and alginate are particularly attractive due to their good film-forming property, moderate mechanical strength, and gas barrier properties with a unique colloidal nature. Recently, zinc oxide nanoparticles ( $\mathrm{ZnO}$-NPs) have become well known for their antimicrobial and UV-light barrier properties. The addition of $\mathrm{ZnO}-\mathrm{NPs}$ to biopolymers has improved the film's properties and showed strong antimicrobial and UV barrier properties [3]. For these reasons, $\mathrm{ZnO}-\mathrm{NPs}$ have been applied to food packaging. However, the antimicrobial activity and membrane properties will depend on the amount of $\mathrm{ZnO}-\mathrm{NPs}$ used. Therefore, the main purpose of this study was to 


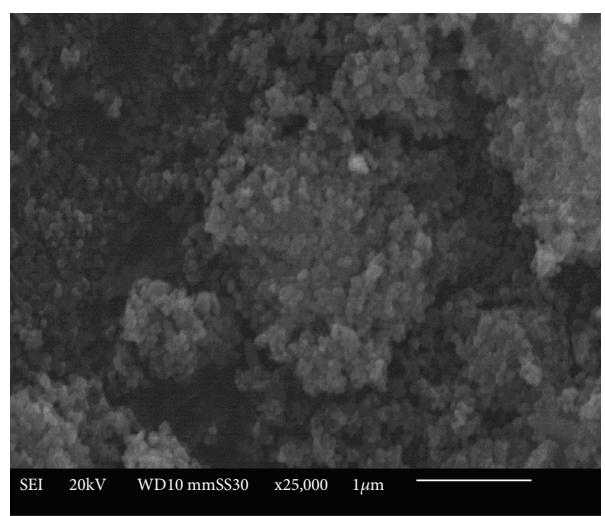

(a)

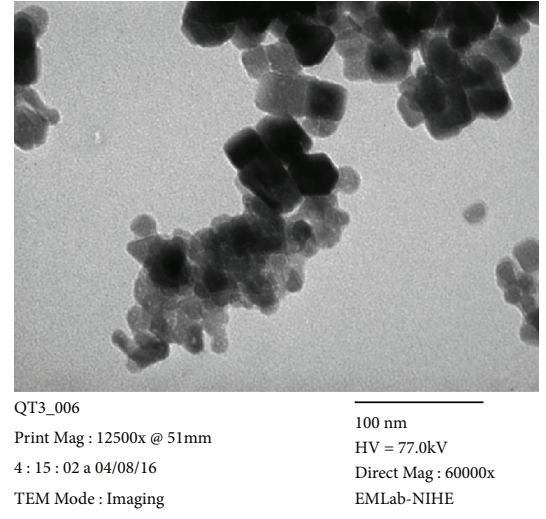

(b)

FIGURE 1: (a) SEM photographs of ZnO-NPs at magnification of 25,000x and (b) TEM photographs of ZnO-NPs at magnification of 125,000x.

develop pectin/alginate films by mixing $\mathrm{ZnO}-\mathrm{NPs}$ with different contents and evaluate the effect of them on the properties of the film.

\section{Materials and Methods}

2.1. Materials and Sample Preparation. Sodium alginate (AG), with a molecular weight $\left(M_{\mathrm{w}}\right)$ of $1.2 \times 10^{6} \mathrm{Da}$, was purchased from Lianyungang Zhongda Seaweed Industrial Co. Ltd. (China). Glycerol and calcium chloride were purchased from Xilong Co. Ltd., China. The BHI medium was purchased from Sigma-Aldrich (St. Louis, USA).

The pectin (P) powder and $\mathrm{ZnO}-\mathrm{NPs}$ were obtained at the LAB of the University of Technology and Education, which belongs to the University of Danang, Vietnam.

The pectin powder was extracted from Yanang leaves using a heating method with an optimum temperature of $88^{\circ} \mathrm{C}$ and time of 75 minutes and in a $6.5 \%$ citric acid solution. The extracted mixture was precipitated with $96 \%$ ethanol. Then, the mixture was centrifuged ( $4000 \mathrm{rpm}$ for $10 \mathrm{~min}$ ) and washed three times with $96 \%$ ethanol. The pectin precipitate was dried at $60^{\circ} \mathrm{C}$, and the dried pectin was ground into a flour. The degree of methyl esterification (DE) measurement value was 48.36 , and the $M_{\mathrm{w}}$ measurement value was $111,105 \mathrm{Da}$.

The $\mathrm{ZnO}-\mathrm{NPs}$ were synthesized by the following sol-gel method: First, $1.1 \mathrm{~g}$ of $\mathrm{Zn}\left(\mathrm{CH}_{3} \mathrm{COO}\right)_{2} \cdot 2 \mathrm{H}_{2} \mathrm{O}$ was dissolved with $50 \mathrm{ml}$ diethylene glycol. The mixture was stirred continuously for one hour at $80^{\circ} \mathrm{C}$. Then, $50 \mathrm{ml}$ of a $0.1 \mathrm{M}$ $\mathrm{LiOH}$ solution was added to the solution. After stirring for 5 minutes at $80^{\circ} \mathrm{C}$, the white precipitate formed. The mixture was centrifuged (4000 rpm for 10 minutes) and washed three times with distilled water and then washed three times with $96 \%$ ethanol to remove the nonreactive and excess ions. The size of $\mathrm{ZnO}-\mathrm{NPs}$ was from 20 to $40 \mathrm{~nm}$ (Figure 1).

The pectin/alginate film-forming aqueous solutions were prepared with $2 \% w / v$ at the proportion of pectin:alginate $1: 1 \mathrm{w} / \mathrm{w}$. Powdered calcium chloride was used at $0.01 \mathrm{~g} / \mathrm{g}$ polymer and glycerol as a plasticizer at 50\% (\% $w / w$ of polymer), and both were blended into the pectinalginate film-solution. The $\mathrm{ZnO}-\mathrm{NPs}$ were added in the pectin/alginate films with glycerol and fabricated with four levels of ZnO-NPs, namely, 0.5, 2.5, 5, and $25 \mathrm{~g} / 100 \mathrm{~g}$ of blended polymer. The mixture was homogenized using a homogenizer at speed of $400 \mathrm{rpm}$ in 15 minutes, and after that, it was stored at $4{ }^{\circ} \mathrm{C}$ and $90 \% \mathrm{RH}$ for degassing. To control the film thickness, the volume of each filmforming solution poured into a $15 \mathrm{~cm} \times 15 \mathrm{~cm}$ mold was always $60 \mathrm{~g}$. Films were dried at $25^{\circ} \mathrm{C}$ and at $52 \pm 1 \%$ relative humidity $(\mathrm{RH})$ for $24 \mathrm{~h}$ by using a fan at speed of $1500 \mathrm{rpm}$.

The dried films were removed from the mold and dipped in $5 \% \mathrm{CaCl}_{2}$ solution for $20 \mathrm{~min}$ to enable crosslinking [4]. Films were dried at $40^{\circ} \mathrm{C}$ for two hours in the oven (UFE 500, Memmert). Films were stored at $52 \pm 1 \%$ $\mathrm{RH}$ and $25 \pm 1^{\circ} \mathrm{C}$ for 5 days prior to testing.

2.2. Thickness. The thickness of the films was measured using a Mitutoyo Dial Thickness Gauge (Model PCM 137, No. 2046S, Japan) with an accuracy of $0.01 \mathrm{~mm}$ at 10 random positions for each film. The average standard deviation was about $5 \%$ of the average thickness. The tests were repeated three times.

2.3. Tensile Property Measurements and \% Elongation at Break. The tensile properties and \% elongation at break of the samples were measured using an Instron 1141 (Instron Ltd., Canton, USA) with the procedure according to ASTM D882-10 [5]. The samples were prepared as sheets using a gauge length and width of $100 \mathrm{~mm}$ and $25 \mathrm{~mm}$, respectively. The initial grip separation was set at $125 \mathrm{~mm} / \mathrm{min}$. The elongation at break was calculated by dividing the elongation at the moment of rupture by the initial gauge length and multiplying by 100 . The samples were conditioned at $52 \pm 1 \% \mathrm{RH}$ and $25^{\circ} \mathrm{C}$ for $48 \mathrm{~h}$ prior to testing. There were ten sample measurements.

2.4. Film Solubility. The films were cut into square $1 \mathrm{~cm} \times 1 \mathrm{~cm}$ pieces and dried to a constant weight in a vacuum oven at $60^{\circ} \mathrm{C}$ for 24 hours to obtain the initial film dry weight $\left(W_{\mathrm{d}}\right)$. Each film was then placed in a bottle containing $20 \mathrm{ml}$ distilled water for 24 hours under gentle agitation and controlled temperature at $25^{\circ} \mathrm{C}$. The films were then dried 
under the same conditions to obtain the dry weight of waterleached film $\left(W_{\mathrm{ws}}\right)$. The tests were performed in triplicate. The film solubility was calculated using

$$
\% \text { solubility }=\frac{\left(W_{\mathrm{d}}-W_{\mathrm{ws}}\right)}{W_{\mathrm{d}}} \times 100 .
$$

2.5. Water Contact Angle. Drop shape analysis (DSA30E, Krüss Co. Ltd., Germany) was used to observe the water contact angle. The samples were prepared as sheets with a dimension of $1 \mathrm{~cm} \times 5 \mathrm{~cm}$. Water was dropped onto the surface of the sheets, and images were taken automatically every $20 \mathrm{~s}$ for $2 \mathrm{~min}$. Samples were kept at $25^{\circ} \mathrm{C}$ and 52 $\pm 1 \% \mathrm{RH}$ at least $48 \mathrm{~h}$ prior to testing. The measurements were average from three samples for each formulation [6].

2.6. Water Vapor Permeability (WVP) and Water Vapor Transmission Rate (WVTR). The WVP of the films was measured gravimetrically at $25 \pm 1^{\circ} \mathrm{C}$ according to ASTM E96-00 (ASTM, 2000). Film specimens with an approximately $8 \mathrm{~cm}$ diameter were mounted on the aluminum cups containing $10 \mathrm{~g}$ of silica gel. Paraffin was used to fix the film specimen on the wide rim of an aluminum cup [7]. The sealed cups were then weighed and kept in desiccators with a saturated solution of $\mathrm{Mg}\left(\mathrm{NO}_{3}\right)_{2}$ salt that provided $52 \pm 1 \% \mathrm{RH}$ at $25 \pm 1^{\circ} \mathrm{C}$ throughout the experiment. The weight gain of the aluminum cups covered with the films was recorded every 10 hours for 5 days [8]. All tests were conducted in triplicate. The WVP and WVTR were calculated using

$$
\begin{aligned}
& \mathrm{WVP}=\frac{w \cdot x}{t \cdot A \cdot P_{\mathrm{o}} \cdot(\mathrm{RH} 1-\mathrm{RH} 2)}\left(\mathrm{kg} \cdot \mathrm{m} / \mathrm{Pa} \cdot \mathrm{m}^{2} \cdot \mathrm{s}\right), \\
& \mathrm{WVTR}=\frac{w}{t \cdot A}\left(\mathrm{~kg} / \mathrm{m}^{2} \cdot \mathrm{s}\right),
\end{aligned}
$$

where $w / t$ is the permeation rate (g/day) that was calculated by a linear regression of the mass gain versus time $\left(R^{2}>0.99\right), x$ is the film average thickness $(\mathrm{mm}), A$ is the permeation area $\left(23.76 \mathrm{~cm}^{2}\right), P_{\mathrm{o}}$ is the partial water vapor pressure at test temperature $\left(3159 \mathrm{kPa}\right.$ at $\left.25^{\circ} \mathrm{C}\right)$, and $\left(\mathrm{RH}_{1}-\mathrm{RH}_{2}\right)$ is the difference in relative humidity between the two sides of the film [9].

2.7. Moisture Sorption Isotherm. The films were cut into a $3 \mathrm{~cm} \times 3 \mathrm{~cm}$ squares and dried in a hot air oven at $105^{\circ} \mathrm{C}$ for $3 \mathrm{~h}$ before being placed in desiccators containing dried silica gel for 2 days. The specimens were then placed in several different desiccators containing various kinds of saturated salt solutions to maintain the constant relative humidity at $11.2 \%, 33.5 \%, 53.1 \%, 64.8 \%, 75.1 \%, 85.5 \%$, and $93.7 \%$. A cotton wool soaked with $96 \%$ ethanol was used as a fungistatic agent in the desiccators containing the salt solutions with a high relative humidity. The specimens were weighed daily until equilibrium was obtained. Equilibrium was achieved when the change in weight did not exceed $0.1 \%$ after being weighed for three consecutive times. The equilibrium moisture content (EMC) (g water/
$100 \mathrm{~g}$ dry solid) of the films at each relative humidity was calculated using

$$
\mathrm{EMC}=\frac{W_{\mathrm{e}}}{W_{\mathrm{i}}}\left(M_{\mathrm{i}}+1\right)-1
$$

where $W_{e}$ is the equilibrium weight of the film specimen $(g), W_{i}$ is the initial weight of the film specimen $(g)$, and $M_{i}$ is the initial moisture content of the film specimen (g water/100 g dry solid) [10, 11]. All measurements were performed in triplicate.

2.8. Transparency and Light Transmission of Films. Each film sample was cut into a rectangular piece and directly mounted between two spectrophotometer magnetic cells. The transparency and light transmission of the films were measured at selected wavelengths between 320 and $800 \mathrm{~nm}$ using a UV-Vis spectrophotometer (Model 8451A, HewlettPackard Co., Santa Clara, CA, USA). The film transparency was calculated with

$$
\text { Transparency }=-\log \frac{T_{600}}{x}(1 / \mathrm{mm}) \text {, }
$$

where $T_{600}$ is the fractional transmittance at $600 \mathrm{~nm}$ and $x$ is the film thickness $(\mathrm{mm})$ [12].

2.9. Oxygen Permeability and Oxygen Transmission Rate. The oxygen permeability (OP) and oxygen transmission rate (OTR) were measured using a Mocon Instruments tool (OX-TRAN ${ }^{\circledR}$ Model 2/21 Series, Mocon Inc., USA). The measurements were taken using $6 \mathrm{~cm} \times 6 \mathrm{~cm}$ film samples at $23 \pm 2^{\circ} \mathrm{C}, 75 \% \mathrm{RH}$, and $760 \mathrm{mmHg}$ following the standard method [13]. The results are the average over at least three replicate measurements. The OP was calculated by

$$
\mathrm{OP}=\frac{\mathrm{OTR} \cdot l}{\Delta P}\left(\mathrm{~kg} \cdot \mathrm{m} / \mathrm{Pa} \cdot \mathrm{m}^{2} \cdot \mathrm{s}\right)
$$

where OTR is the value of oxygen transmission rate, $l$ is the thickness of the film, and $\Delta P$ is the difference between oxygen partial pressures between the two sides of the film $(\mathrm{Pa})$.

2.10. Antimicrobial Action of Film-Forming Solutions. The antimicrobial activities of the film-forming solutions incorporating the ZnO-NPs were evaluated by the well diffusion method in agar against E. coli, Saccharomyces cerevisiae, Colletotrichum gloeosporioides, and Aspergillus niger. The microorganisms were prepared for the test as follows: E. coli was aseptically inoculated in BHI broth and subsequently incubated at $37^{\circ} \mathrm{C}$ for $16 \mathrm{~h}$. Saccharomyces cerevisiae, Aspergillus niger, and Colletotrichum gloeosporioides were aseptically inoculated in Sabouraud broth and subsequently incubated at $30^{\circ} \mathrm{C}$ for $16 \mathrm{~h}$. The evaluation process was as follows: The Sabouraud agar medium was used for S. cerevisiae, Aspergillus niger, and Colletotrichum gloeosporioides, and the $\mathrm{BHI}$ agar medium was used for E. coli. All were poured into petri dishes. After solidification, wells at $5 \mathrm{~mm}$ in diameter were cut from the agar and $0.1 \mathrm{ml}$ of the film-forming 


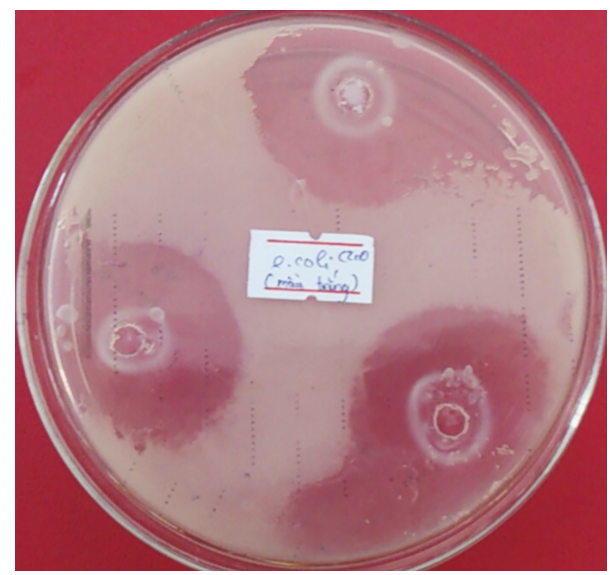

Figure 2: Evaluation image of antibacterial action by the "zone inhibition method."

solution was carefully poured inside. Next, a $1 \mathrm{ml}$ suspension containing $10^{6} \mathrm{CFU} / \mathrm{ml}$ of each investigated microorganism was spread in the specific agar medium. After incubating for $48 \mathrm{~h}$ at $30^{\circ} \mathrm{C}$ for $\mathrm{S}$. cerevisiae, Aspergillus niger, and Colletotrichum gloeosporioides and $48 \mathrm{~h}$ at $37^{\circ} \mathrm{C}$ for E. coli, all plates were inspected. The diameters of the inhibition zones were measured (in $\mathrm{cm}$ ) with a ruler on the underside of the petri dish. For example, the image that showed the antibacterial activity of film-forming solution against E. coli is shown in Figure 2. All measurements were performed in triplicate $[14,15]$.

\subsection{Attenuated Total Reflectance-Fourier Transform} Infrared (ATR-FTIR) Spectroscopy. The reaction between the pectin, alginate, and $\mathrm{ZnO}-\mathrm{NPs}$ was monitored by ATRFTIR (Thermo Nicolet 6700, USA). The samples were prepared as thin films (about $60 \mu \mathrm{m}$ ). The IR spectra were measured at wavelengths from $500 \mathrm{~cm}^{-1}$ to $4000 \mathrm{~cm}^{-1}$ and with a resolution of $4 \mathrm{~cm}^{-1}$.

2.12. Statistical Analysis. Statistics were determined with a completely randomized design with an analysis of variance (ANOVA) using Minitab software (version 16.2.3.0; Minitab Inc., USA). Fisher's tests were used to compare the difference among the mean values of the film specimens' properties at the level of 0.05 . All experiments were conducted in triplicate.

\section{Results and Discussion}

3.1. Thickness and Mechanical Properties. The thickness and mechanical properties of the P/AG films with various $\mathrm{ZnO}$ NP contents are presented in Table 1. The thicknesses of the P/AG films that contain the $\mathrm{ZnO}-\mathrm{NPs}$ is higher than for the P/AG only film. The increase in $\mathrm{ZnO}-\mathrm{NP}$ content from 0 to $25 \mathrm{~g} / 100 \mathrm{~g}$ of blended polymer led to an increase in the film thickness from 52.4 to $74.6 \mu \mathrm{m}$. The increase in the thickness was not only attributed to the higher solid content of nanocomposite films $\mathrm{ZnO}$-NPs but also attributed to their structure. Similar results were reported by Shahmohammadi Jebel and Almasi [16].
The tensile strength (TS) and \% elongation at break (E) for the films with various $\mathrm{ZnO}-\mathrm{NP}$ contents equilibrated at $25 \pm 1^{\circ} \mathrm{C}$ and $52 \pm 1 \% \mathrm{RH}$ are shown in Table 1 . There was an increase in tensile strength from 21.71 to $41.56 \mathrm{MPa}$ when increasing the $\mathrm{ZnO}-\mathrm{NP}$ content from 0.5 to $5 \mathrm{~g} / 100 \mathrm{~g}$ of blended polymer. On the other hand, the increase in the $\mathrm{ZnO}-\mathrm{NP}$ concentration from 5 to $25 \mathrm{~g} / 100 \mathrm{~g}$ of blended polymer reduced the tensile strength from 41.56 to $12.79 \mathrm{MPa}$. The tensile strength was the highest when the $\mathrm{ZnO}$-NPs were added at a concentration of $5 \mathrm{~g} / 100 \mathrm{~g}$ of blended polymer, where it reached $191.4 \%$ of the tensile strength for the P/ AG film.

The change in elongation is similar to that of tensile strength. Changes in tensile strength and elongation values may be due to the formation of hydrogen links between the pectin, alginate's hydroxyl groups, and oxygen atoms in the $\mathrm{ZnO}-\mathrm{NPs}[17,18]$. Moreover, a low concentration of $\mathrm{ZnO}$ NPs had a negligible effect on the formation of hydrogen bonds between the $\mathrm{OH}$ and the $\mathrm{COOH}$ groups in the pectin/alginate matrix, as well as the formation of bonds between the $\mathrm{Ca}^{2+}$ and the $\mathrm{COO}^{-}$groups of the pectin and alginate chains. The pectin and alginate chains thereby adopted a structure that resembles an "egg-box" model.

The decrease in TS and $\mathrm{E}$ of the film with $25 \mathrm{~g} \mathrm{ZnO}-\mathrm{NPs} /$ $100 \mathrm{~g}$ polymer was probably due to agglomeration of the $\mathrm{ZnO}-\mathrm{NPs}$, the nonuniform distribution of the $\mathrm{ZnO}-\mathrm{NPs}$, and the recrystallization of the $\mathrm{ZnO}-\mathrm{NPs}$ in the polymer matrix. These factors caused discontinuous cracks in the polymer matrix and resulted in a sudden decrease in the TS and E. A similar result was observed when adding $\mathrm{CuO}$ NPs and ZnO-NPs into a carrageenan matrix [18].

3.2. Solubility and Water Contact Angle. The water contact angle $(\theta)$ is the most common parameter used to describe the hydrophilicity of film surfaces. Hydrophilic membranes possess a contact angle of $0^{\circ}<\theta<90^{\circ}$, while hydrophobic membranes have a contact angle of $90^{\circ}<\theta<180^{\circ}$ [19]. Table 2 shows the solubility and water contact angle for the film specimens.

Results showed that adding ZnO-NPs to the P/AG film at the amount of 0.5 to $5 \mathrm{~g} / 100 \mathrm{~g}$ of blended polymer did not significantly change the water contact angle. However, the water contact angle for the film-incorporated $\mathrm{ZnO}-\mathrm{NPs}$ with $25 \mathrm{~g} /$ $100 \mathrm{~g}$ of blended polymer was lower than the other films. Reducing the water contact angle may be due to an increase in surface roughness at high $\mathrm{ZnO}-\mathrm{NP}$ concentrations.

The solubility values for the specimens trended to the decrease with increasing $\mathrm{ZnO}$-NP content, except for the $\mathrm{ZnO}-\mathrm{NP}$ content of $25 \mathrm{~g} / 100 \mathrm{~g}$ of blended polymer. These results indicate that the addition of the $\mathrm{ZnO}$-NPs reduced the number of hydroxyl groups and charged groups $\left(-\mathrm{COO}^{-}\right)$. Moreover, the length of the polymer increased due to the formation of links between the $\mathrm{ZnO}-\mathrm{NPs}$, pectin, and alginate. Consequently, the solubility of the films was reduced. The $\mathrm{ZnO}-\mathrm{NP}$ content in the $25 \mathrm{~g} / 100 \mathrm{~g}$ of blended polymer was more than necessary for creating hydrogen bonds such that it probably had a negative effect on the cross-linking between the $\mathrm{Ca}^{2+}$ ion, the pectin, and the alginate carboxyl groups. This increased the solubility value. 
TABLE 1: Thickness and mechanical properties (tensile strength $=\mathrm{TS}$; $\%$ elongation $=\% \mathrm{E}$ ) of $\mathrm{P} / \mathrm{AG}$ films with various $\mathrm{ZnO}-\mathrm{NP}$ contents.

\begin{tabular}{lccc}
\hline $\begin{array}{l}\text { ZnO-NP content } \\
\text { (g/100 of } \\
\text { blended polymer) }\end{array}$ & Thickness $(\mu \mathrm{m})$ & TS $(\mathrm{MPa})$ & $\% \mathrm{E}(\%)$ \\
\hline 0 & $43.8 \pm 2.11^{\mathrm{d}}$ & $21.71 \pm 1.23^{\mathrm{d}}$ & $0.86 \pm 0.04^{\mathrm{c}}$ \\
0.5 & $52.4 \pm 2.5^{\mathrm{c}}$ & $32.59 \pm 1.6^{\mathrm{c}}$ & $1.89 \pm 0.05^{\mathrm{b}}$ \\
2.5 & $56.8 \pm 2.83^{\mathrm{b}}$ & $36.43 \pm 0.98^{\mathrm{b}}$ & $1.93 \pm 0.05^{\mathrm{b}}$ \\
5 & $58.1 \pm 2.08^{\mathrm{b}}$ & $41.56 \pm 1.94^{\mathrm{a}}$ & $2.32 \pm 0.06^{\mathrm{a}}$ \\
25 & $74.6 \pm 3.25^{\mathrm{a}}$ & $12.79 \pm 0.58^{\mathrm{e}}$ & $0.85 \pm 0.04^{\mathrm{c}}$ \\
\hline
\end{tabular}

Alphabets in a column indicate a significant difference at $P<0.05$ by Duncan's multiple.

TABLE 2: Effect of ZnO-NP contents on the solubility and water contact angle of $\mathrm{P} / \mathrm{AG}$ films.

\begin{tabular}{lcc}
\hline $\begin{array}{l}\mathrm{ZnO}-N P \text { contents } \\
(\mathrm{g} / 100 \mathrm{~g} \text { of blended polymer })\end{array}$ & ${\text { Contact angle }\left(^{\circ}\right)}$ & Solubility $(\%)$ \\
\hline 0 & $73.85 \pm 6.4^{\mathrm{a}}$ & $30.38 \pm 1.3^{\mathrm{a}}$ \\
0.5 & $72.9 \pm 4.5^{\mathrm{a}}$ & $27.34 \pm 1.8^{\mathrm{ab}}$ \\
2.5 & $72.5 \pm 2.9^{\mathrm{a}}$ & $23.16 \pm 2.1^{\mathrm{b}}$ \\
5 & $70.73 \pm 4.1^{\mathrm{a}}$ & $22.49 \pm 3.1^{\mathrm{b}}$ \\
25 & $54.07 \pm 7.4^{\mathrm{b}}$ & $26.1 \pm 1.5^{\mathrm{ab}}$ \\
\hline
\end{tabular}

Alphabets in a column indicate a significant difference at $P<0.05$ by Duncan's multiple.

TABLE 3: WVP and WVTR of P/AG films with various $\mathrm{ZnO}-\mathrm{NP}$ contents.

\begin{tabular}{lcc}
\hline $\begin{array}{l}\text { ZnO-NP contents }(\mathrm{g} / 100 \mathrm{~g} \text { of } \\
\text { blended polymer })\end{array}$ & $\begin{array}{c}\mathrm{WVP} \times 10^{-14} \\
\left(\mathrm{~kg} \cdot \mathrm{m} / \mathrm{m}^{2} \cdot \mathrm{Pa} \cdot \mathrm{s}\right)\end{array}$ & $\begin{array}{c}\mathrm{WVRT} \times 10^{-7} \\
\left(\mathrm{~kg} / \mathrm{m}^{2} \cdot \mathrm{s}\right)\end{array}$ \\
\hline 0 & $1.01 \pm 0.029^{\mathrm{a}}$ & $4.226 \pm 0.121^{\mathrm{a}}$ \\
0.5 & $0.576 \pm 0.018^{\mathrm{b}}$ & $2.148 \pm 0.069^{\mathrm{b}}$ \\
2.5 & $0.447 \pm 0.008^{\mathrm{c}}$ & $1.949 \pm 0.035^{\mathrm{b}}$ \\
5 & $0.414 \pm 0.02^{\mathrm{cd}}$ & $1.486 \pm 0.069^{\mathrm{c}}$ \\
25 & $0.381 \pm 0.019^{\mathrm{d}}$ & $1.437 \pm 0.069^{\mathrm{c}}$ \\
\hline
\end{tabular}

Alphabets in a column indicate a significant difference at $P<0.05$ by Duncan's multiple.

Thus, the film solubility trended to increase when the $\mathrm{ZnO}$ $\mathrm{NP}$ content was $25 \mathrm{~g} / 100 \mathrm{~g}$ of blended polymer.

3.3. WVP and WVTR of P/AG Films. Table 3 shows WVP and WVTR of film specimens. The WVP values of the specimens decreased from 1.01 to $0.414 \mathrm{~kg} \cdot \mathrm{m} / \mathrm{m}^{2} \cdot \mathrm{Pa} \cdot \mathrm{s}(59 \%)$, and WVTR values decreased from 4.226 to $1.486 \mathrm{~kg} / \mathrm{m}^{2} \cdot \mathrm{s}$ (64.8\%), when increasing the $\mathrm{ZnO}-\mathrm{NP}$ content from 0 to $5 \mathrm{~g} / 100 \mathrm{~g}$ of blended polymer. This may be due to the formation of the hydrogen bonds between the pectin, alginate matrix, and oxygen atoms in the ZnO-NPs, which increases the adhesion of the biopolymer matrix and can reduce the diffusion of the water molecules in the material. A similar result was reported by Almasi et al. [20]. On the other hand, the even distribution of the $\mathrm{ZnO}-\mathrm{NPs}$ with smaller sizes and

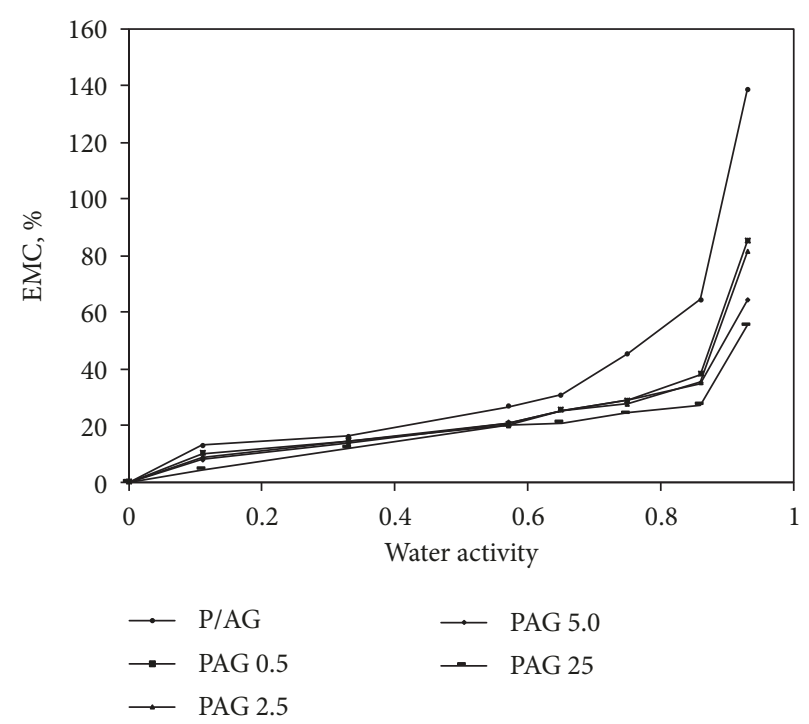

FIgURe 3: Moisture sorption isotherms of $\mathrm{P} / \mathrm{AG}$ films incorporated with various $\mathrm{ZnO}-\mathrm{NP}$ contents at $25 \pm 1^{\circ} \mathrm{C}$.

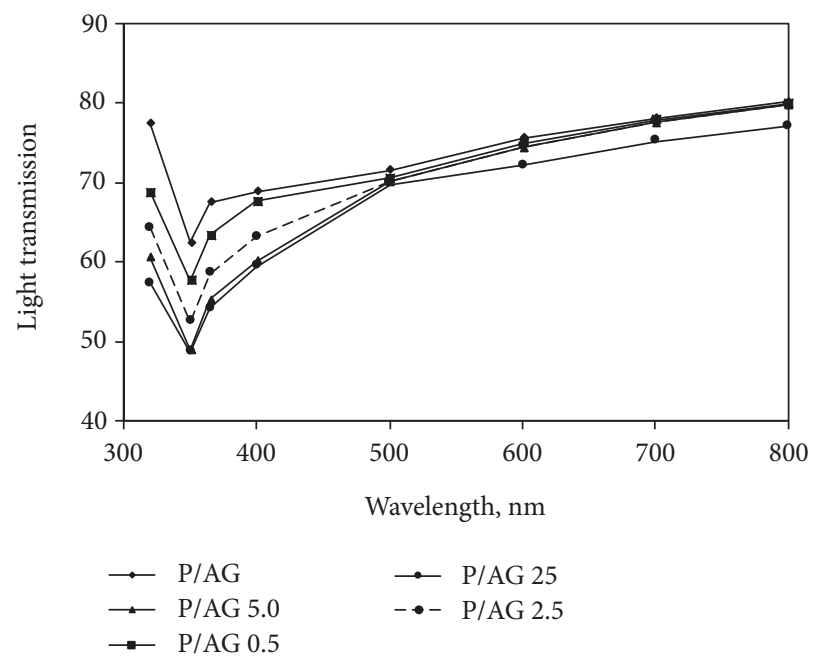

FIGURE 4: Light transmission of the films.

filling of the microvoids should reduce the length of a free path for water uptake. Similar results were reported for the effect of ZnO-NPs on the WVP of biopolymer-based nanocomposites $[3,21]$. There was no significant change in the WVP and WVTR values of the sample when increasing the content of the $\mathrm{ZnO}-\mathrm{NPs}$ from 5 to $25 \mathrm{~g} / 100 \mathrm{~g}$ of blended polymer, which may be due to the maximum reduction of the hydrophilic groups, such as $\mathrm{OH}$ and $\mathrm{COOH}$ in the polymer.

3.4. Moisture Sorption Isotherm. The moisture absorption of the P/AG film was higher than that of P/AG films with the $\mathrm{ZnO}-\mathrm{NPs}$ in the range of water activity between 0.86 and 0.93 (Figure 3). A similar result was reported by Galus and Lenart [22]. The film's moisture absorption decreased as the $\mathrm{ZnO}-\mathrm{NP}$ content increased. However, there was no 
TABLE 4: Transparency of P/AG films with various $\mathrm{ZnO}-\mathrm{NP}$ contents.

\begin{tabular}{lccccc}
\hline ZnO-NP contents $(\mathrm{g} / 100 \mathrm{~g}$ of blended polymer) & 0 & 0.5 & 2.5 & 5 & 25 \\
\hline Transparency values $(1 / \mathrm{mm})$ & $3.24 \pm 0.02^{\mathrm{b}}$ & $3.26 \pm 0.01^{\mathrm{b}}$ & $3.25 \pm 0.03^{\mathrm{b}}$ & $3.17 \pm 0.02^{\mathrm{ab}}$ & $3.01 \pm 0.02^{\mathrm{a}}$ \\
\hline
\end{tabular}

Alphabets in a column indicate a significant difference at $P<0.05$ by Duncan's multiple.

TABle 5: OP and OTR of P/AG films with various $\mathrm{ZnO}-\mathrm{NP}$ contents.

\begin{tabular}{lcc}
\hline $\begin{array}{l}\mathrm{ZnO}-\mathrm{NP} \text { contents } \\
(\mathrm{g} / 100 \mathrm{~g} \text { of blended polymer })\end{array}$ & $\begin{array}{c}\mathrm{OP} \times 10^{-19} \\
\left(\mathrm{~kg} \cdot \mathrm{m} / \mathrm{m}^{2} \cdot \mathrm{Pa} \cdot \mathrm{s}\right)\end{array}$ & $\begin{array}{c}\mathrm{OTR} \times 10^{-11} \\
\left(\mathrm{~kg} / \mathrm{m}^{2} \cdot \mathrm{s}\right)\end{array}$ \\
\hline 0 & $270.86 \pm 9.79^{\mathrm{a}}$ & $158.65 \pm 16.17^{\mathrm{a}}$ \\
0.5 & $253.85 \pm 15.35^{\mathrm{a}}$ & $137.51 \pm 6.95^{\mathrm{b}}$ \\
2.5 & $191.87 \pm 12.44^{\mathrm{b}}$ & $89.82 \pm 3.68^{\mathrm{c}}$ \\
5 & $110.79 \pm 7.74^{\mathrm{d}}$ & $51.87 \pm 3.98^{\mathrm{d}}$ \\
25 & $132.92 \pm 7.45^{\mathrm{c}}$ & $48.84 \pm 3.55^{\mathrm{d}}$ \\
\hline
\end{tabular}

significant change in the moisture absorption between the $\mathrm{P} /$ AG films and the P/AG films with the ZnO-NPs in the water activity range of 0 to 0.75 . Based on the results obtained for the solubility, WVP, mechanical properties, and moisture sorption isotherm, it is recognized that these trends are due to the formation of hydrogen bonding between the $\mathrm{OH}$ groups of the pectin, alginate, and oxygen atoms of the $\mathrm{ZnO}-\mathrm{NPs}$. The reduction in moisture absorption may be due to the reduction of the free $\mathrm{OH}$ groups in the membrane. On the other hand, a uniform dispersion of smaller $\mathrm{ZnO}-\mathrm{NPs}$ and filling of microvoids produces a decrease in the length of the free path for water uptake.

3.5. Transparency and Light Transmission of Films. Figure 4 shows the light transmission of film specimens. Light transmission decreases in the wavelength range of 320 to $350 \mathrm{~nm}$ (UV light) and reaches the lowest value at $350 \mathrm{~nm}$. The light transmittance of films containing $\mathrm{ZnO}-\mathrm{NPs}$ is always lower than that of films without the $\mathrm{ZnO}-\mathrm{NPs}$. The higher the $\mathrm{ZnO}$ concentration in the film, the lower the light transmission at the wavelength range of 320 to $350 \mathrm{~nm}$. This result shows that $\mathrm{ZnO}-\mathrm{NPs}$ in the film have absorbed ultraviolet light. This result is consistent with that of Khodaiyana et al. [23] who observed that the UV absorbance of the nanocomposite polymers increased as the $\mathrm{ZnO}-\mathrm{NP}$ content increased. They also observed that a $\mathrm{ZnO}-\mathrm{Np}$ content greater than $1 \%$ was necessary to induce UV filtration in a kefiran biopolymer. There is no significant difference in light transmittance between films containing $\mathrm{ZnO}-\mathrm{NPs}$ and P/AG films in the wavelength range of 500 to $800 \mathrm{~nm}$, except for P/AG films with a $\mathrm{ZnO}-\mathrm{NP}$ content of $25 \mathrm{~g} / 100 \mathrm{~g}$ of blended polymer.

Table 4 shows the transparency of the films with various $\mathrm{ZnO}-\mathrm{NP}$ contents. The transparency for the films containing 0.5 to $5 \mathrm{~g} / 100 \mathrm{~g}$ blended polymer of $\mathrm{ZnO}$-NPs was not significantly different from the P/AG film. However, the addition of $\mathrm{ZnO}-\mathrm{NPs}$ with $25 \mathrm{~g} / 100 \mathrm{~g}$ of blended polymer into the films decreased the transparency value. The reduction of transparency of the films with a concentration of $25 \mathrm{~g} \mathrm{ZnO}$ NPs/100 g polymer may be due to the over-distribution of the $\mathrm{ZnO}-\mathrm{NPs}$ in the pectin/alginate network.
3.6. Oxygen Permeability and Oxygen Transmission Rate. The $\mathrm{OP}$ and OTR of P/AG and P/AG films with various $\mathrm{ZnO}-\mathrm{NP}$ contents are presented in Table 5.

The addition of $\mathrm{ZnO}-\mathrm{NP}$ to the P/AG films led to a reduced oxygen permeability. The lowest reduction occurred when the $\mathrm{ZnO}-\mathrm{NP}$ concentration reached $5 \mathrm{~g} / 100 \mathrm{~g}$ of polymer. The OP values decreased by $59 \%$, and OTR values decreased by $67.3 \%$ with the addition of $5 \mathrm{~g} \mathrm{ZnO-NPs/100 \textrm {g }}$ of blended polymer. The permeability coefficient of a substance is determined by the formula $P=D \times S$, in which $D$ is the diffusion coefficient and $S$ is the solubility coefficient [24]. The reduction of OP and OTR can be attributed to the distribution of the $\mathrm{ZnO}$ nanoparticles in the film matrix, which led to a reduced oxygen diffusion. The increase in OP when the concentration of $\mathrm{ZnO}-\mathrm{NPs}$ was $25 \mathrm{~g} / 100 \mathrm{~g}$ of blended polymer was probably due to reducing the hydrogen bonds in the pectin/alginate matrix and reducing the interaction between P/AG and $\mathrm{ZnO}-\mathrm{NPs}$, due to structural changes in the polymer matrix. Therefore, the diffusion coefficient increased leading to an increase in the oxygen permeability of these films. This result shows the possibility of using $\mathrm{P} / \mathrm{AG}$ membranes with $\mathrm{ZnO}-\mathrm{NPs}$ in food preservation to inhibit oxidation.

3.7. Antimicrobial Action of Film-Forming Solutions. The antimicrobial activities of the P/AG ZnO-NPs films against Escherichia coli, Saccharomyces cerevisiae, Colletotrichum gloeosporioides, and Aspergillus niger are shown in Figure 5.

The inhibition zone increased with the increase of the $\mathrm{ZnO}-\mathrm{NP}$ concentration in the range of 0.5 to $5 \mathrm{~g} / 100 \mathrm{~g}$ of polymer. However, when increasing the concentration from $5 \mathrm{~g}$ to $25 \mathrm{~g} / 100 \mathrm{~g}$ of polymer, the inhibitory zone did not increase. This may be related to the decrease of the diffusion ability of the ZnO-NPs in the agar at high concentrations. The antimicrobial effect was due to the $\mathrm{ZnO}-\mathrm{NPs}$ because the pure $\mathrm{P} / \mathrm{AG}$ film that did not contain $\mathrm{ZnO}-\mathrm{NPs}$ was not antibacterial. The inhibitory effect of the $\mathrm{ZnO}-\mathrm{NPs}$ against Aspergillus niger and Colletotrichum gloeosporioides was greater than that against E. coli and Saccharomyces cerevisiae. It is believed that the antimicrobial activity of $\mathrm{ZnO}$ NPs is mainly dependent on the cell wall structure of the microorganisms. In almost mold, the hyphal cell wall consists of a single, 80 to $150 \mathrm{~nm}$ layer composed of chitin and $\beta$-glucan. In contrast, the 200 to $600 \mathrm{~nm}$ thick yeast cell wall has three layers [25]. The cell wall of E. coli (Gramnegative bacteria) is composed of a complex structure with thin peptidoglycan layer surrounded by an outer membrane $[26,27]$. The antimicrobial activity of the P/AG films with $\mathrm{ZnO}-\mathrm{NPs}$ was the highest when the $\mathrm{ZnO}-\mathrm{NP}$ concentration was $5 \mathrm{~g} / 100 \mathrm{~g}$ of blended polymer. The results of the study on the antimicrobial properties of P/AG films with $\mathrm{ZnO}$ NPs support the use of this material to preserve food products, especially products that are susceptible to mold damage. 


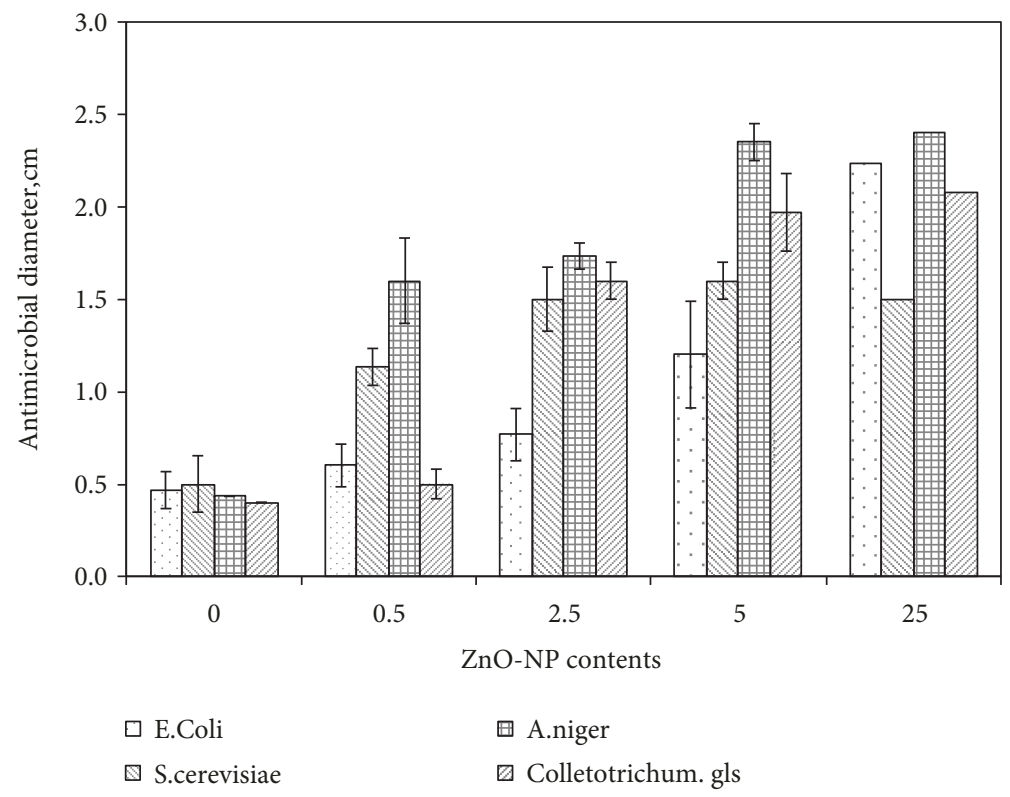

FIGURE 5: Antimicrobial activities of P/AG films with various $\mathrm{ZnO}-\mathrm{NP}$ contents.

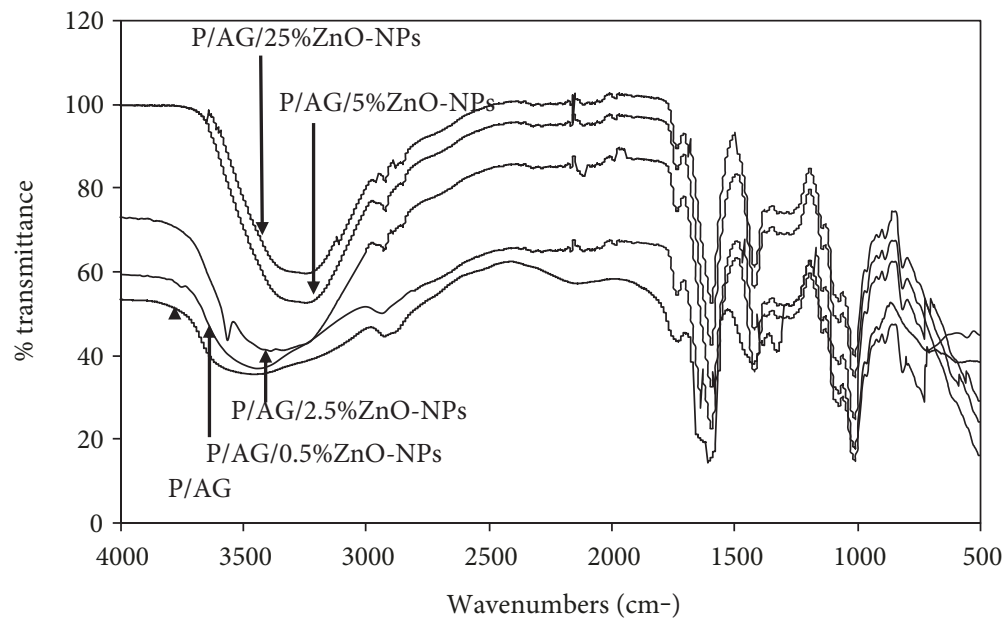

FIGURE 6: FTIR spectra of P/AG films incorporated with various $\mathrm{ZnO}-\mathrm{NP}$ contents.

Moreover, ZnO-NPs have a negligible negative effect on human cells according to Reddy et al. [28].

3.8. FTIR Spectra of P/AG Films with ZnO-NPs. The ATR-FTIR analysis demonstrates the interaction between the $\mathrm{ZnO}-\mathrm{NPs}$, pectin, and alginate. The results are shown in Figure 6.

The results show that the spectra for all films have characteristic peaks at $4000-500 \mathrm{~cm}^{-1}$. The P/AG films exhibited the major band at $1630 \mathrm{~cm}^{-1}$, which is the characteristic peak of $\mathrm{C}=\mathrm{O}$ stretching/hydrogen bonding coupled with a $\mathrm{COO}^{-}$ group of pectin and alginate [25]. The absorption peaks at 1400 and $1440 \mathrm{~cm}^{-1}$ are related to the stretching bands of the $\mathrm{COO}^{-}$groups, and the peak at $3410 \mathrm{~cm}^{-1}$ was induced by the $\mathrm{OH}$ groups. The ATR-FTIR spectra of P/AG/ZnONPs films show that the peaks at 3410, 2890, 1630, and $1420 \mathrm{~cm}^{-1}$ were shifted to $3300-3200,2920-2910,1597$, and $1410 \mathrm{~cm}^{-1}$, respectively. Shifting of the adsorption peaks indicates that hydrogen bonds between the oxygen atoms of $\mathrm{ZnO}-\mathrm{NPs}$ and the $\mathrm{OH}$, the $\mathrm{COOH}$, and the $\mathrm{CH}_{3}$ (hexane) groups of pectin/alginate matrix occurred. These results confirm that the addition of $\mathrm{ZnO}$-NPs can improve the water resistance, oxygen resistance, and mechanical properties of the P/AG films. The reason could be that the $\mathrm{OH}$ and the $\mathrm{COOH}$ groups of the pectin/alginate matrix are able to form hydrogen bonds with oxygen groups in the ZnO-NPs.

\section{Conclusions}

The addition of $\mathrm{ZnO}-\mathrm{NPs}$ to pectin and alginate films changed some physicochemical properties of films compared to films without the $\mathrm{ZnO}$-NPs. There was a decrease in the solubility, moisture absorption, UV light transmission, WVP, WVTR, OP, and the OTR of the P/AG films with ZnO-NPs compared to the films without them. In contrast, there was an increase in tensile strength, elongation at break, and 
antimicrobial properties of the P/AG films with ZnO-NPs compared to the films without them. In this work, the change was the highest when the $\mathrm{ZnO}-\mathrm{NP}$ content in the film was $5 \mathrm{~g} / 100 \mathrm{~g}$ of blended polymer. The ATR-FTIR analysis indicated that hydrogen bonds between the ZnO-NPs and pectin/alginate matrices were formed. These results suggest the possibility of using $\mathrm{P} / \mathrm{AG} / \mathrm{ZnO}$-NPs film in food preservation and that they may be better than pectin/alginate films.

\section{Data Availability}

The data used to support the findings of this study are available from the corresponding author upon request.

\section{Conflicts of Interest}

The authors declare that they have no conflicts of interest.

\section{Acknowledgments}

The authors gratefully acknowledge the financial support from the "911 Scholarship" for Ph.D. students from the Ministry of Education, Vietnam. We would also like to thank the Faculty of Chemical Engineering, University of Technology \& Education (UTE) and University of Technology \& Science (DUT), the University of Danang for the equipment and facility support. We wish to thank the Center of Excellence in Materials Science and Technology, Chiang Mai University, for the financial support under the administration of Materials Science Research Center, Faculty of Science, Chiang Mai University.

\section{References}

[1] J. W. Rhim, H. M. Park, and C. S. Ha, "Bio-nanocomposites for food packaging applications," Progress in Polymer Science, vol. 38, no. 10-11, pp. 1629-1652, 2013.

[2] S. Tunç and O. Duman, "Preparation of active antimicrobial methyl cellulose/carvacrol/montmorillonite nanocomposite films and investigation of carvacrol release," LWT - Food Science and Technology, vol. 44, no. 2, pp. 465-472, 2011.

[3] S. Shankar, X. Teng, G. Li, and J. W. Rhim, "Preparation, characterization, and antimicrobial activity of gelatin/ $\mathrm{ZnO}$ nanocomposite films," Food Hydrocolloids, vol. 45, pp. 264$271,2015$.

[4] F. L. Seixasa, F. R. B. Turbianib, P. G. Salomãob, R. P. Souza, and M. L. Gimenes, "Biofilms composed of alginate and pectin: effect of concentration of crosslinker and plasticizer agents," Chemical Engineering Transactions, vol. 32, pp. 1693-1698, 2013.

[5] ASTM, "Standard test methods for tensile properties of thin plastic sheeting D882-10," in Annual Book of ASTM, American Society for Testing and Materials, Philadelphia, PA, USA, 2010.

[6] K. Jantanasakulwong, N. Leksawasdi, P. Seesuriyachan, S. Wongsuriyasak, C. Techapun, and T. Ougizawa, "Reactive blending of thermoplastic starch and polyethylene-graftmaleic anhydride with chitosan as compatibilizer," Carbohydrate Polymers, vol. 153, pp. 89-95, 2016.

[7] P. Rachtanapun and N. Rattanapanone, "Synthesis and characterization of carboxymethyl cellulose powder and films from
Mimosa pigra," Journal of Applied Polymer Science, vol. 122, no. 5, pp. 3218-3226, 2011.

[8] K. N. Turhan and F. Sahbaz, "Water vapor permeability, tensile properties and solubility of methylcellulose-based edible films," Journal of Food Engineering, vol. 61, no. 3, pp. 459466, 2004.

[9] C. M. Bitencourt, C. S. Fávaro-Trindade, P. J. A. Sobral, and R. A. Carvalho, "Gelatin-based films additivated with curcuma ethanol extract: antioxidant activity and physical properties of films," Food Hydrocolloids, vol. 40, pp. 145-152, 2014.

[10] P. Rachtanapun, "Shelf life study of salted crackers in pouch by using computer simulation model," Chiang Mai Journal Science, vol. 34, no. 2, pp. 209-218, 2007.

[11] P. Rachtanapun and R. Suriyatem, "Prediction models for moisture sorption isotherm of soy protein isolate/carboxymethyl chitosan blend films," Journal of Agricultural Science and Technology, vol. A2, pp. 50-57, 2012.

[12] S. Rawdkuen, P. Suthiluk, D. Kamhangwong, and S. Benjakul, "Mechanical, physico-chemical, and antimicrobial properties of gelatin-based film incorporated with catechin-lysozyme," Chemistry Central Journal, vol. 6, no. 1, pp. 1-10, 2012.

[13] A. S. T. M. D3985-10, "Standard test method for oxygen gas transmission rate through plastic film and sheeting using a coulometric sensor," in Book of Standards, ASTM International, 2010.

[14] S. Suganya, R. Bharathidasan, G. Senthilkumar, P. Madhanraj, and A. Panneerselvam, "Antibacterial activity of essential oil extracted from Coriandrumsativam (L.) and GC-MS analysis," Journal of Chemical and Pharmaceutical Research, vol. 4, no. 3, pp. 1846-1850, 2012.

[15] A. M. Cozmuta, A. Turila, R. Apjok et al., "Preparation and characterization of improved gelatin films incorporating hemp and sage oils," Food Hydrocolloids, vol. 49, pp. 144-155, 2015.

[16] F. Shahmohammadi Jebel and H. Almasi, "Morphological, physical, antimicrobial and release properties of $\mathrm{ZnO}$ nanoparticles-loaded bacterial cellulose films," Carbohydrate Polymers, vol. 149, pp. 8-19, 2016.

[17] L. Shi and S. Gunasekaran, "Preparation of pectin-ZnO nanocomposite," Nanoscale Research Letters, vol. 3, no. 12, pp. 491495, 2008

[18] A. A. Oun and J. W. Rhim, "Carrageenan-based hydrogels and films: effect of $\mathrm{ZnO}$ and $\mathrm{CuO}$ nanoparticles on the physical, mechanical, and antimicrobial properties," Food Hydrocolloids, vol. 67, pp. 45-53, 2017.

[19] H. Isawi, M. H. el-Sayed, X. Feng, H. Shawky, and M. S. Abdel Mottaleb, "Surface nanostructuring of thin film composite membranes via grafting polymerization and incorporation of ZnO nanoparticles," Applied Surface Science, vol. 385, pp. 268-281, 2016.

[20] H. Almasi, B. Ghanbarzadeh, and A. A. Entezami, "Physicochemical properties of starch-CMC-nanoclay biodegradable films," International Journal of Biological Macromolecules, vol. 46, no. 1, pp. 1-5, 2010.

[21] I. Shahabi-Ghahfarrokhi, F. Khodaiyan, M. Mousavi, and H. Yousefi, "Effect of $\gamma$-irradiation on the physical and mechanical properties of kefiran biopolymer film," International Journal of Biological Macromolecules, vol. 74, no. 3, pp. 343-350, 2015.

[22] S. Galus and A. Lenart, "Development and characterization of composite edible films based on sodium alginate and pectin," Journal of Food Engineering, vol. 115, no. 4, pp. 459-465, 2013. 
[23] I. Shahabi-Ghahfarrokhi, F. Khodaiyan, M. Mousavi, and H. Yousefi, "Preparation of UV-protective kefiran/nano-ZnO nanocomposites:physical and mechanical properties," International Journal of Biological Macromolecules, vol. 72, pp. 41-46, 2015.

[24] R. J. Ashley, Permeability and Plastics Packaging, Elsevier Applied Science Publishers, London; New York, 1985.

[25] M. R. McGinnis and S. K. Tyring, Medical Microbiology, University of Texas Medical Branch at Galveston, Galveston, TX, USA, 1996.

[26] S. Anitha, B. Brabu, D. J. Thiruvadigal, C. Gopalakrishnan, and T. S. Natarajan, "Optical, bactericidal and water repellent properties of electrospun nanocomposite membranes of cellulose acetate and $\mathrm{ZnO}$," Carbohydrate Polymers, vol. 87, no. 2, pp. 1065-1072, 2012.

[27] S. Paisoonsin, O. Pornsunthorntawee, and R. Rujiravanit, "Preparation and characterization of $\mathrm{ZnO}$-deposited $\mathrm{DBD}$ plasma-treated PP packaging film with antibacterial activities," Applied Surface Science, vol. 273, pp. 824-835, 2013.

[28] K. M. Reddy, K. Feris, J. Bell, D. G. Wingett, C. Hanley, and A. Punnoose, "Selective toxicity of zinc oxide nanoparticles to prokaryotic and eukaryotic systems," Applied Physics Letters, vol. 90, no. 21, article 213902, 2007. 


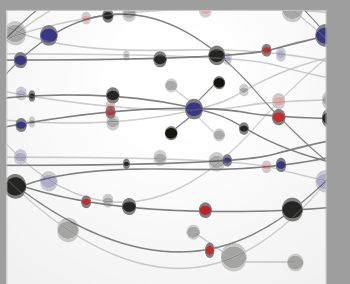

The Scientific World Journal
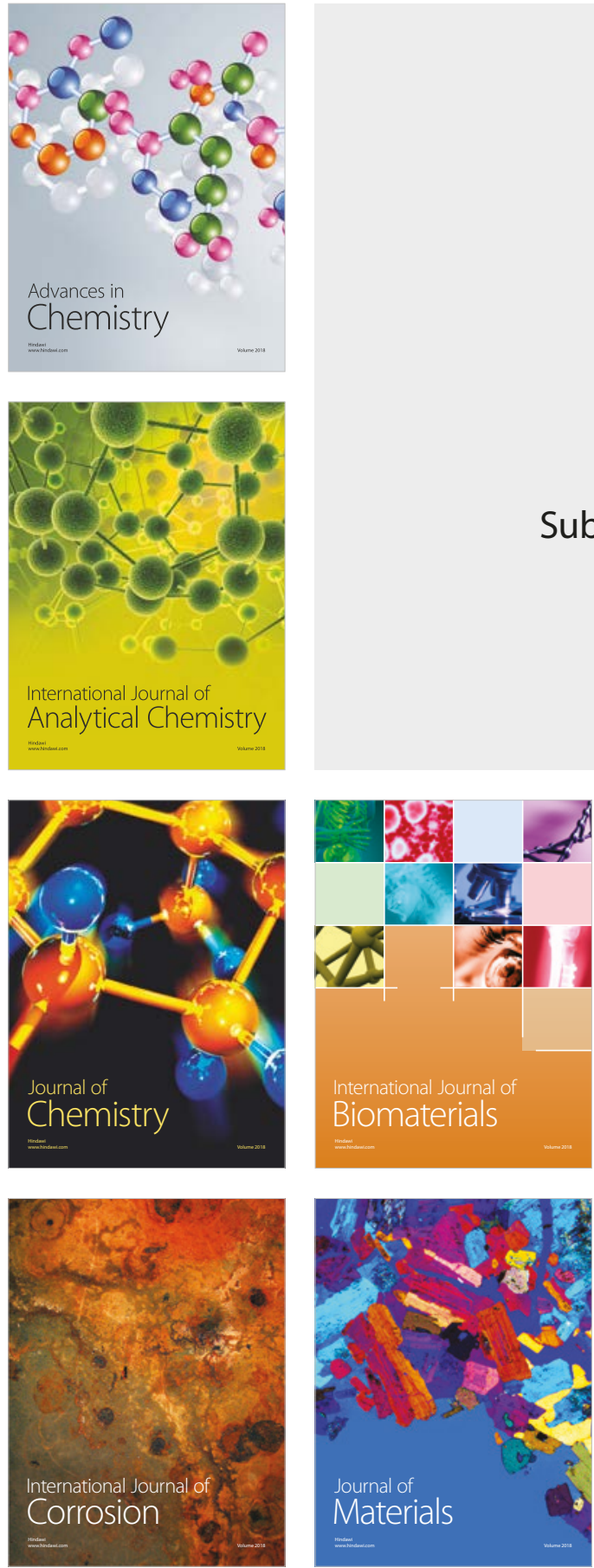

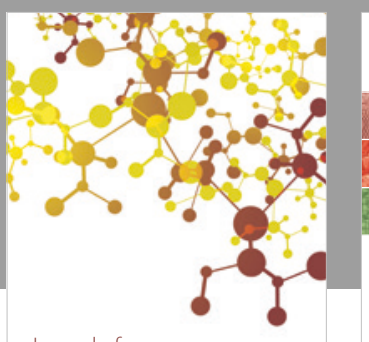

Journal of

Applied Chemistry
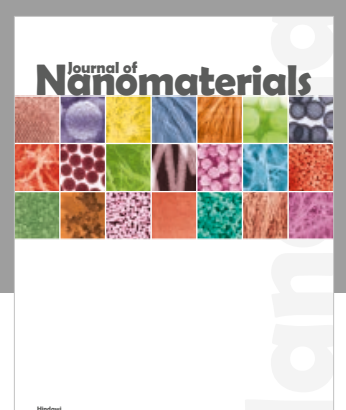

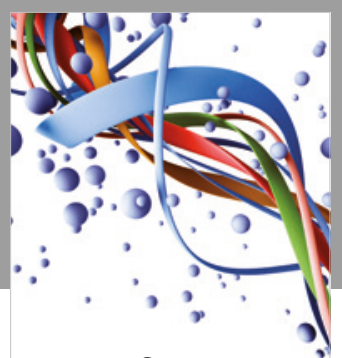

Scientifica

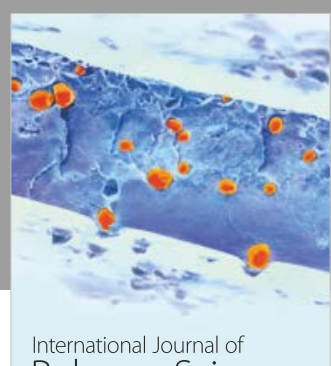

Polymer Science

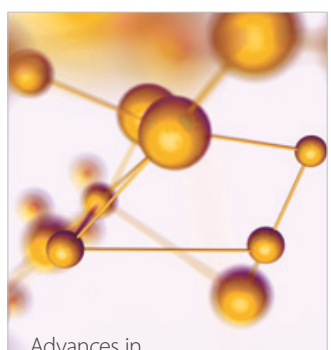

Physical Chemistry
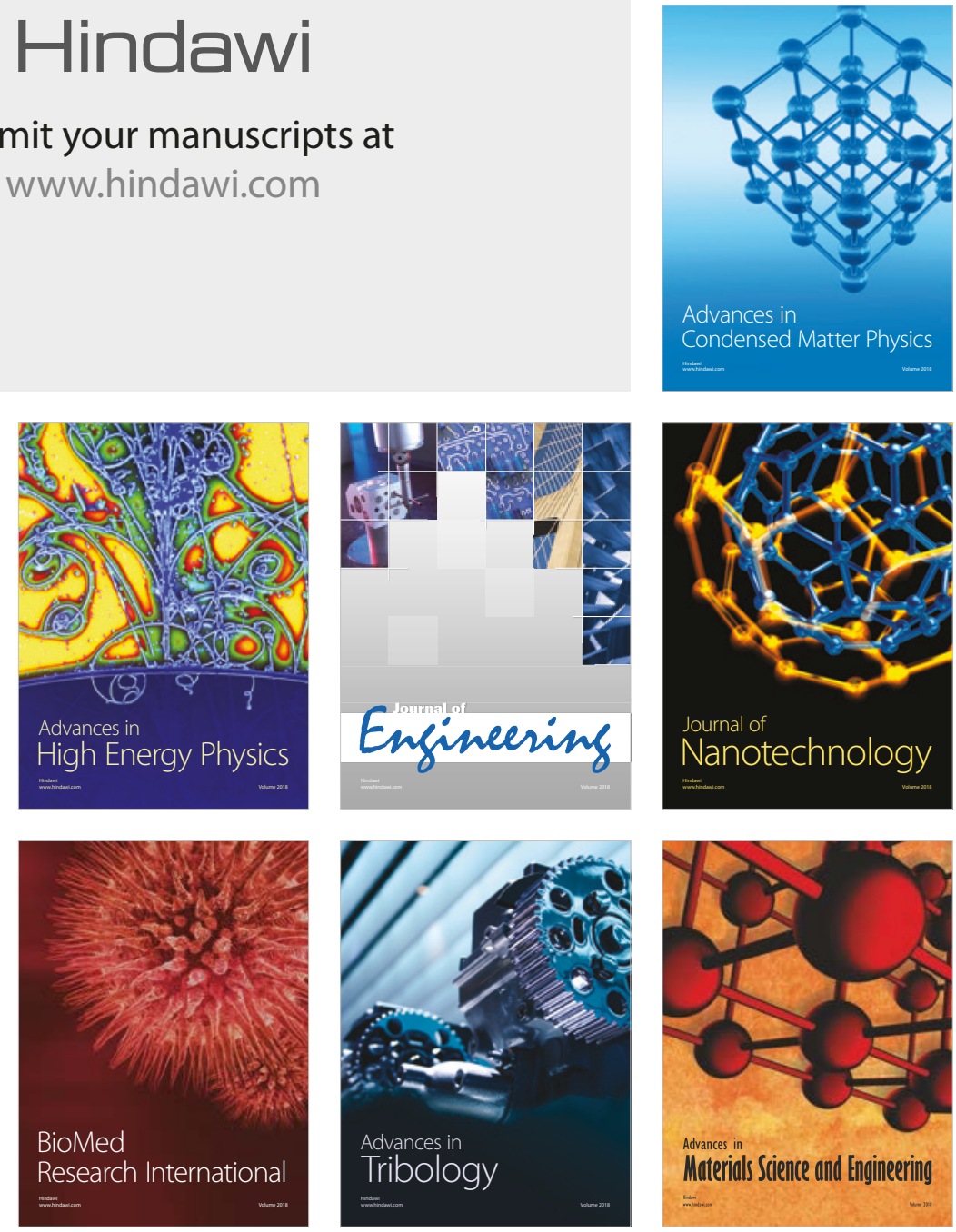